\title{
THE INHIBITORY EFFECT OF TROPOLONE AND HINOKITIOL ON THE MYCELIUM GROWTH OF PHOMA NARCISSI IN VITRO
}

\author{
Alicja Saniewska, Marian Saniewski \\ Research Institute of Pomology and Floriculture, Pomologiczna 18, 96100 Skierniewice, Poland \\ e mail: asaniew@insad.pl
}

Received: 26.02 .2007

$\mathrm{S} \mathrm{u} \mathrm{m} \mathrm{m} \mathrm{a} \mathrm{r} \mathrm{y}$

Tropolone and hinokitiol ( $\beta$ thujaplicin) that are present in heartwood of several Cupressaceae trees are known for their antibacterial, antifungal and insecticidal properties. In the present studies it was showed that tropolone and hinokitiol greatly inhi bited in vitro, on PDA medium, the mycelium growth of Phoma narcissi, a pathogen of Hippeastrum and other species of fami ly Amaryllidaceae. Total inhibition of the mycelium growth of Phoma narcissi took place at a tropolone concentration of 6.0 $\mu \mathrm{g} \cdot \mathrm{cm}^{3}$ and at a hinokitiol concentration of $50.0 \mu \mathrm{g} \cdot \mathrm{cm}^{3}$. Fungi cidal doses of tropolone and hinokitiol for the mycelium growth of Phoma narcissi were also documented. The results presented in this paper are discussed with data available in literature on the antifungal action of tropolone and hinokitiol on other species of pathogenic fungi.

Key words: Phoma narcissi, mycelium growth, tropolone, hino kitiol ( $\beta$ thujaplicin)

\section{INTRODUCTION}

Hinokitiol ( $\beta$-thujaplicin) is a tropolone-related compound (Fig. 1) that is present in the heartwood of several Cupressaceae trees, such as Chamaecyparis obtusa Sieb. et Zucc., Thuja plicata D. Don (A rima et al. 2003; Yamano et al. 2005), Thujopsis dolabrata Sieb. et Zucc. hondai Makino (Morita et al. 2003), Hiba arboruitae (Fallik and Grinberg, 1992), Cupressus lusitanica ( $\mathrm{Z} \mathrm{h}$ a o and $\mathrm{S}$ a k a i, 2003). Tropolone and hinokitiol are known to have insecticidal and antimicrobial activity (Trust and Coombs, 1973; Morita et al. 2003; Arima et al. 2003; Yamano et al. 2005; B a y a et al. 2001). Fallik and Grinberg (1972) showed that hinokitiol inhibited in vitro spore germination and mycelial growth of Botrytis cinerea, Alternaria alternata, Rhizopus stolonifer and Mucor spp. and Morita et al. (2003) documented antifungal activity of tropolone and hinokitiol against Pythium aphanidermatum, Thanatephorus cucumeris, Fusarium solani, Botryotinia fuckeliana, Phomopsis obscurans, Colletotrichum orbiculare and Colletotrichum lagenarium. Earlier in 1989 it was reported in two patents that hinokitiol had strong antifungal activity against Helicobasidium mompa and Rosellinia necatrix (cited after Morita et al. 2003). The mechanism of antimicrobial and insecticidal activity of tropolone and hinokitiol is unknown but it was documented that tropolone greatly inhibited polyphenol oxidase (Khan and Andrawis, 1985; Valero et al. 1991), and tropolone and hinokitiol showed inhibitory activity toward metalloproteases such as carboxypeptidase A and collagenase (Morita et al. 2003).

In the present studies we showed a strong inhibitory effect of tropolone and hinokitiol on the mycelium growth of Phoma narcissi, a pathogen of Hippeastrum and other species of Amaryllidaceae (S aniewska, 1998).

\section{MATERIAL AND METHODS}

The stock culture of Phoma narcissi (Aderh.) Boerema, de Gruyter et Noordel. was maintained on potato-dextrose-agar (PDA-Merck), slants at $25^{\circ} \mathrm{C}$ in the dark.

The effect of tropolone and hinokitiol ( $\beta$-thujaplicin) (purchased from Sigma-Aldrich Chemicals) on the mycelium growth of Phoma narcissi on potato-dextrose-agar medium was investigated. These compounds were used at the following final concentrations: tropolone 2.0, 4.0, 6.0, 8.0, 10.0 and $50.0 \mu \mathrm{g} \cdot \mathrm{cm}^{-3}$ and hinokitiol - 10.0, 15.0, 25.0, 50.0, 75.0 and $100.0 \mu \mathrm{g} \cdot \mathrm{cm}^{-}{ }^{3}$ in PDA medium. Hinokitiol was dissolved in $50 \%$ of ethanol and tropolone was dissolved in distilled and sterilized water, and then they were added to PDA medium after sterilization at a temperature of about $50^{\circ} \mathrm{C}$. Five $\mathrm{mm}$ diameter plugs were taken from 7-day-old culture of 
Phoma narcissi, and placed in the middle of $90 \mathrm{~mm}$ Petri dishes containing PDA medium supplemented earlier with the tested compounds. The control plates contained the culture growing on pure PDA, without any additions and supplemented with ethanol at an appropriate concentration. Five Perti dishes were used as an experimental unit and the trial was repeated twice. The incubation was conducted in darkness at $25^{\circ} \mathrm{C}$. After 2,4 and 6 days of incubation, the diameter of the fungal colonies was measured in two perpendicular directions.

Additionally, the mycelial plugs from which the colonies did not develop were transferred into the plates containing clean PDA and observed during the 6-day-incubation.

The data were subjected to an analysis of variance and Duncan's multiple range test at $5 \%$ of significance was used for means separation.

\section{RESULTS AND DISCUSSION}

Tropolone applied to the PDA medium at a concentration of 2.0 and $4.0 \mu \mathrm{g} \cdot \mathrm{cm}^{-3}$ inhibited the mycelium growth of Phoma narcissi in 81.4 and $97.2 \%$, respectively, after 7 days incubation, but tropolone at a concentration of $6.0 \mu \mathrm{g} \cdot \mathrm{cm}^{-3}$ or higher totally inhibited the mycelium growth of the pathogen (Fig. 2 and 3). It should be mentioned that the disks of mycelium Phoma narcissi incubated during 7 days on PDA supplemented with tropolone at a concentration of 6.0 and $8.0 \mu \mathrm{g} \cdot \mathrm{cm}^{-3}$ and transferred to clean PDA started the mycelium growth but in a weaker degree, proportionally to the tropolone concentration; 10 $\mu \mathrm{g} \cdot \mathrm{cm}^{-3}$ of tropolone or higher concentrations were fungicidal and the lack of growth of the mycelium Phoma narcissi was observed (data not presented).

Hinokitiol applied to the PDA medium at a concentration of $10.0,15.0$ and $25.0 \mu \mathrm{g} \cdot \mathrm{cm}^{-3}$ limited the mycelium growth of Phoma narcissi in 50.5, 61.5 and $88.4 \%$, respectively, after 7 days incubation and a concentration of the compound at $50.0 \mu \mathrm{g} \cdot \mathrm{cm}^{-3}$ and higher totally inhibited the mycelium growth of the pathogen (Fig. 4). It was documented that hinokitiol at a concentration of $100.0 \mu \mathrm{g} \cdot \mathrm{cm}^{-3}$ had fungicidal activity (data not presented). On PDA the mycelium of Phoma narcissi was smoky-grey, whereas its reverse was grey-olivaceous, locally dark-grey, with an olivaceous-black center; probably the grey colour of the mycelium is caused by the presence of melanins. The addition of hinokitiol at a low concentration to PDA caused that the mycelium of Phoma narcissi was light-grey or beige on both sides (Fig. 5); it is suggested that hinokitiol as an inhibitor of catechol oxidase ( $\mathrm{K} \mathrm{h}$ a $\mathrm{n}$ and $\mathrm{A} \mathrm{n} \mathrm{d} \mathrm{r} \mathrm{a} \mathrm{w} \mathrm{i} \mathrm{s,} \mathrm{1985;}$ Valero et al. 1991) limited the formation and accumulation of melanins in the mycelium of the pathogen.

Thus, in the case of Phoma narcissi tropolone had a much stronger inhibitory effect on the mycelium growth than hinokitiol (Fig. 2 and 4).

Mortia et al. (2003) showed clear antifungal activity of tropolone on seven species of fungi tested

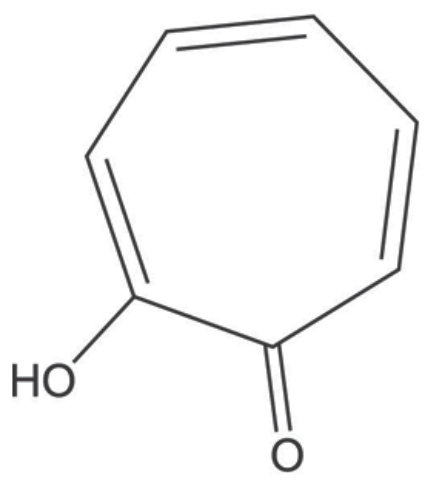

Tropolone

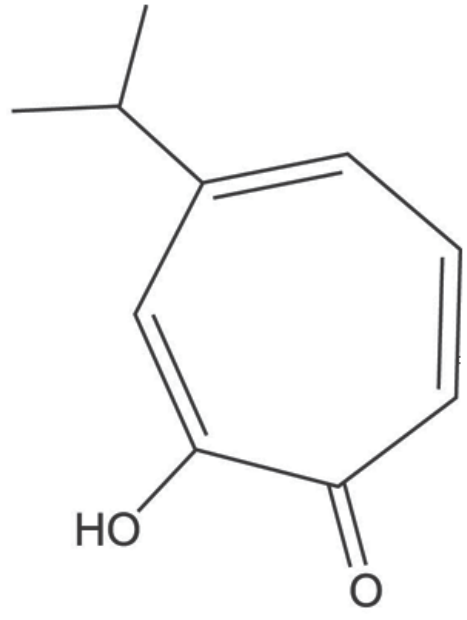

Hinokitiol

Fig. 1. Chemical structures of tropolone and hinokitiol ( $\beta$ thujaplicin) (Morita et al. 2003). 


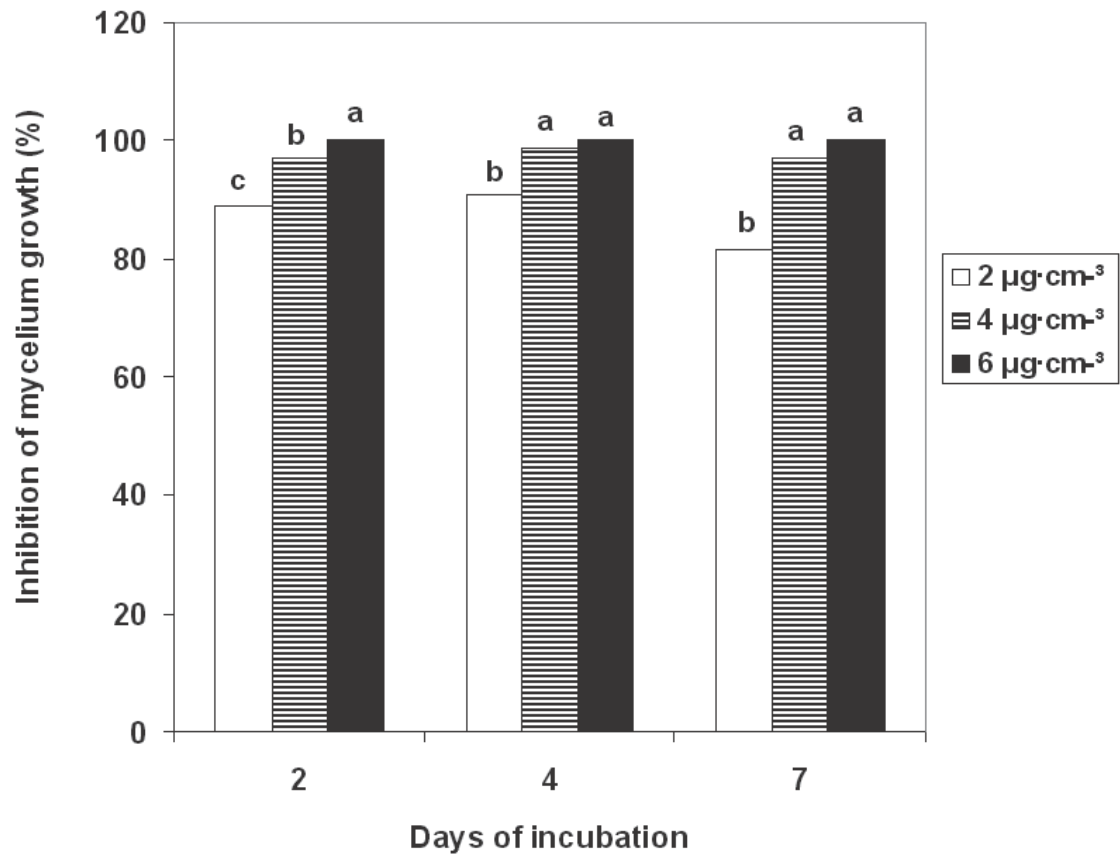

Fig. 2. Inhibitory effect of tropolone on the mycelium growth of Phoma narcissi; surface of the mycelium growth in the control on PDA after 2,4 and 7 days of incubation is $7.1 ; 24.6$ and $59.7 \mathrm{~cm}^{2}$, respectively.

Values followed by the same letter do not differ at $5 \%$ level of significance (Duncan's test).

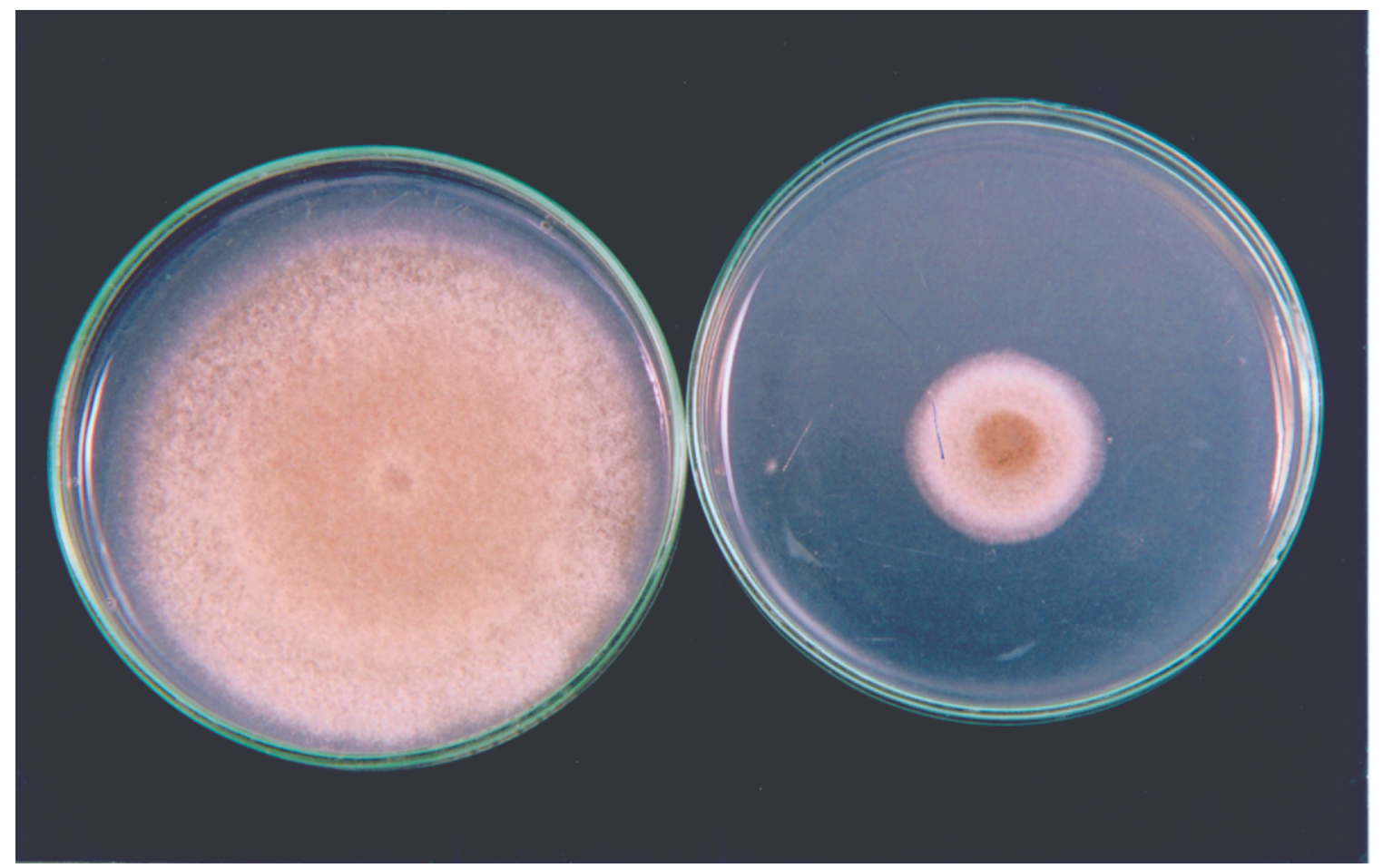

Fig. 3. Inhibitory effect of tropolone at a concentration of $2.0 \mu \mathrm{g} \cdot \mathrm{cm}^{3}$ on the mycelium growth of Phoma narcissi after 7 days incubation; on left control, PDA, on right $\mathrm{PDA}+$ tropolone. 


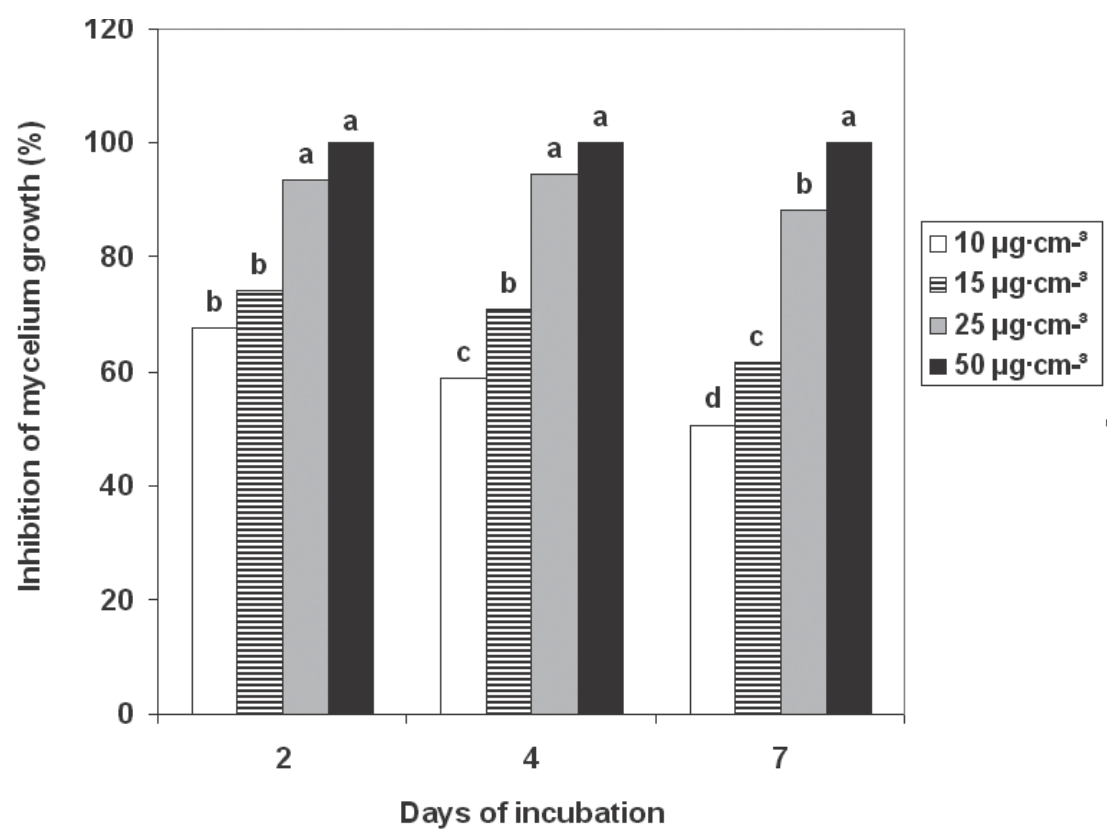

Fig. 4. Inhibitory effect of hinokitiol on the mycelium growth of Phoma narcissi; surface of the mycelium growth in the control on PDA after 2, 4 and 7 days of incubation is $3.1 ; 19.7$ and $50.7 \mathrm{~cm}^{2}$, respectively.

Values followed by the same letter do not differ at 5\% level of significance (Duncan's test).

and the minimum inhibitory concentration on these fungi was in the range of 6.0 to $50.0 \mu \mathrm{g} \cdot \mathrm{cm}^{-}{ }^{3}$, and the antifungal activity of hinokitiol was equal to or lower than that of tropolone.

Madar et al. (1995) isolated from the bark of Cupressus sempervirens two antifungal tropolone glucosides, 6-isopropyltropolone $\beta$-glucoside and 5-(3-hydroxy-3-methyl-trans-1-butenyl)-6-isopropyltropolone $\beta$-glucoside; these compounds inhibited in vitro germination of spores of Diplodia pinea f. sp. cupressi, Seiridium cardinale, Alternaria alternata and Verticillium dahliae. Recently, M o r i t a et al. (2004) documented that isolated from Thujopsis dolabrata $\gamma$-thujaplicin, $\beta$-dolabrin and 4-acetyltropolone, hinokitiol-related compounds, showed antifungal activity on seven species of plant pathogenic fungi.

It is well known that food packages can be made antimicrobial active by the incorporation and immobilization of antimicrobial agents or by surface modification and surface coating. S u p p a k u 1 et al. (2003) present active packaging technologies with an emphasis on antimicrobial packaging and its applications, and hinokitiol is considered as one of safe antimicrobial agents.

\section{Acknowledgement:}

The research was supported by Ministry of Science and Information Society Technologies, Grant No 2 P06R 12526. 

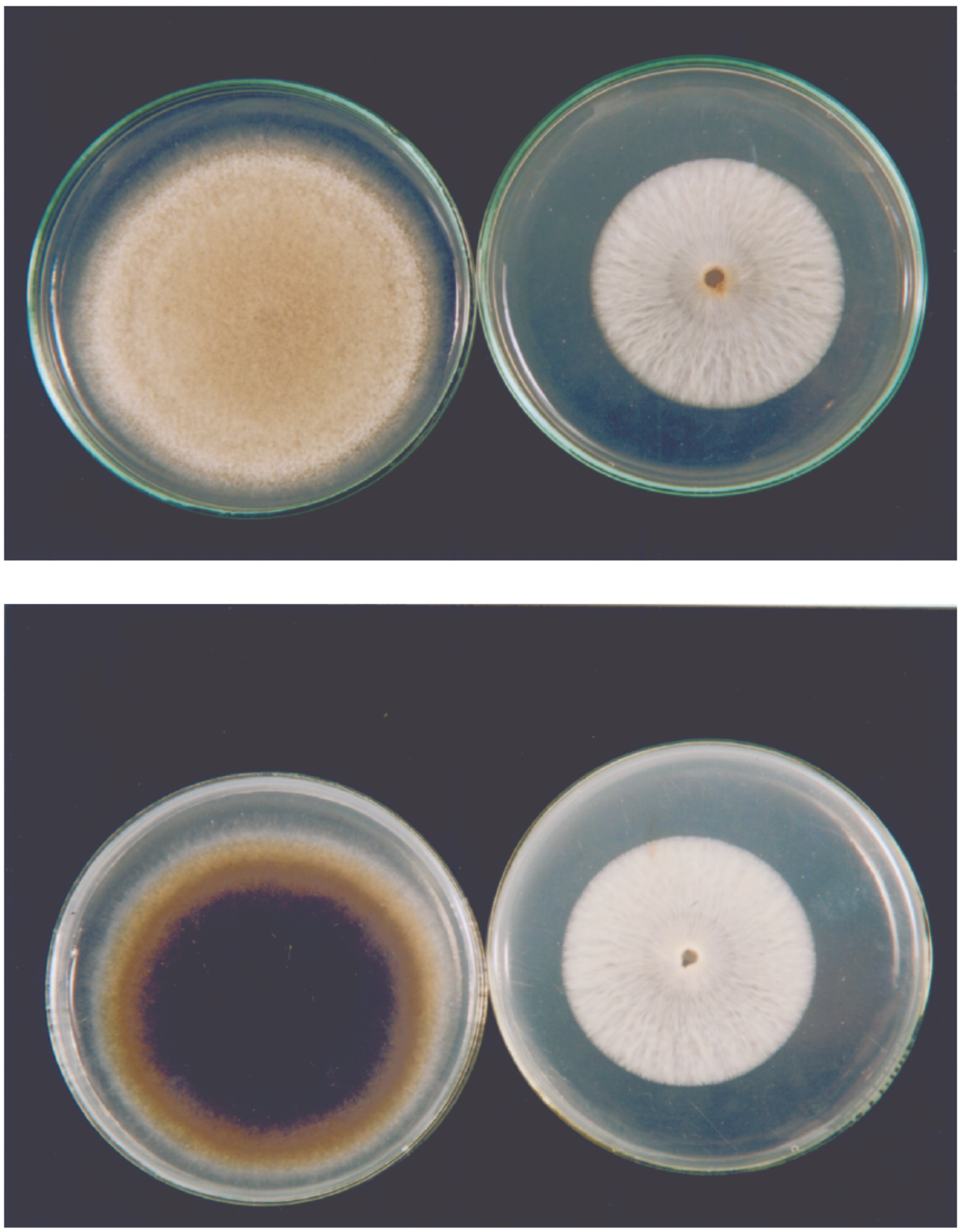

Fig. 5. Inhibitory effect of hinokitiol at a concentration of $15 \mu \mathrm{g} \bullet \mathrm{cm}^{3}$ on the mycelium growth of Phoma narcissi after 10 days of incubation;

upper picture: mycelium from upper side

lower picture: mycelium from lower side

on left control, PDA; on right PDA + hinokitiol. 


\section{REFERENCES}

Arima Y., Naka i Y., H a y a k aw a R., N is h ino T., 2003. Antibacterial effect of $\beta$ thujaplicin on staphylococci iso lated from atopic dermatitis; relationship between chang es in the number of viable bacterial cells and clinical im provement in a eczematous lesion of atopic dermatitis. Can. J. Micrbiol. 19: 13411347.

B a y a M., S o u 1 o u n g a $\mathrm{ng}$ a P., G e 1 h a y e E., Gérardin P., 2001. Fungicidal activity of $\beta$ thujaplicin analogues. Pest Manage. Sci. 57: 833838.

F a 11 i k E., Gri n b e r g S., 1992. Hinokitiol: a natural sub stance that controls postharvest diseases in eggplant and pepper fruits. Postharvest Biol. Technol. 2: 137144.

$\mathrm{K} h$ a $\mathrm{n}$ V., A n d r a w i s A., 1985. Inhibition of mushroom ty rosinase by tropolone. Phytochemistry, 24: 905908.

M a d a r Z., G o t $\mathrm{t} 1$ i e b H. E., C o j o c a r u M., R i o v J., Solel Z., S z t e j n b e r g A., 1995. Antifungal ter penoids produced by cypress after infection by Diplodia pinea f. sp. cupressi. Phytochemistry, 38: 351354.

Morit a Y., Matsumura E., Okabe T., Fukui T., O h e T., I s h i d a N., I n a m or i Y., 2004. Biological activity of beta dolabrin, gamma thujaplicin, and 4 acet yltropolone, hinokitiol related compounds. Biol. Pharm. Bull. 27: 16661669

Morit a Y., M a t s u mura E., O k ab e T., Shibat a M., S u g i u ra M., O h e T., T s u j ib o H., I s h id a N., I n a m o r i Y., 2003. Biological activity of tropolone. Biol. Pharm. Bull. 26: 14871490.

S a n i e w s k a A., 1998. Czynniki biotyczne i abiotyczne hamujące wzrost i rozwój Phoma narcissi (Aderh.) Boer ema, de Gruyter et Noordel / Biotic and abiotic factors inhibiting the growth and development of Phoma narcissi (Aderh.) Boerema, de Gruyter et Noordel. Zeszyty Naukowe Instytutu Sadownictwa i Kwiaciarstwa, Mono grafie i Rozprawy, Skierniewice: 132.

S u p pakul P., Miltz J., S on n eve1d K., B igger S. W., 2003. Active packaging technologies with an emphasis on antimicrobial packaging and its applications. J. Food Sci. 68: 408420 .
Tr u s t T. J., C o o m b s R. W., 1973. Antibacterial activity of $\beta$ thujaplicin. Can. J. Microbiol. 19: 13411347.

Valero E., G a r c i a M or e no M., V a rón R., Garcia $\mathrm{C}$ a r m o n a F., 1991. Time dependent inhibition of grape polyphenol oxidase by tropolone. J. Agric. Food Chem. 39: 10431046.

Y a m a n o H., Y a m a z a k i T., S a to K., S h i g a S., Hagiwara T., O u c h i K., K i s h i m o t o T., 2005. In vitro inhibitory effects of hinokitiol on proliferation of Chlamydia trachomatis. Antimicrob. Agents Chemother 49: 25192521.

$\mathrm{Z}$ h a o J., S a k a i K., 2003. Multiple signalling pathways me diate fungal elicitor induced $\beta$ thujaplicin biosynthesis in Cupressus lusitanica cell cultures. J. Exper. Bot. 54: 647656

\section{Hamujące działanie tropolone i hinokitiolu na wzrost grzybni Phoma narcissi in vitro}

\section{Streszczenie}

Tropolone i hinokitiol ( $\beta$-tujaplicyna), występujące $\mathrm{w}$ wielu gatunkach drzew należących do rodziny Cupressaceae, mają właściwości antybakteryjne, antygrzybowe $\mathrm{i}$ insektycidalne. $\mathrm{W}$ obecnych badaniach wykazano, że tropolone i hinokitiol silnie hamowały in vitro na pożywce PDA wzrost grzybni Phoma narcissi, patogena Hippeastrum i innych gatunków z rodziny Amaryllidaceae. Całkowite zahamowanie wzrostu grzybni Phoma narcissi następowało przy stężeniu tropolone $6,0 \mu \mathrm{g} \cdot \mathrm{cm}^{-}{ }^{3}$ i przy stężeniu hinokitiolu 50,0 $\mu \mathrm{g} \cdot \mathrm{cm}^{-}{ }^{3}$. Fungicidalne stężenia tropolone i hinokitiolu zostały również określone. Wyniki badań własnych zostały przedyskutowane $\mathrm{z}$ dostępnymi danymi w literaturze o antygrzybowym działaniu tropolone i hinokitiolu na inne gatunki grzybów patogenicznych. 